\title{
INFLUENCE OF THE LENGTH OF REMAINING ROOT CANAL FILLING AND POST SPACE PREPARATION ON THE CORONAL LEAKAGE OF ENTEROCOCCUS FAECALIS
}

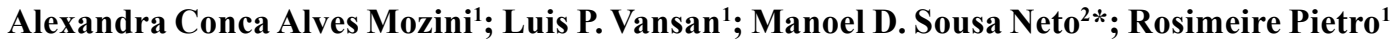 \\ ${ }^{1}$ Faculdade de Odontologia, Universidade de Ribeirão Preto, Ribeirão Preto, SP, Brasil; ${ }^{2}$ Faculdade de Odontologia de Ribeirão \\ Preto, Universidade de São Paulo, Ribeirão Preto, SP, Brasil
}

Submitted: February 18, 2008; Returned to authors for corrections: April 10, 2008; Approved: February 25, 2009.

\begin{abstract}
This study evaluated the sealing ability of different lengths of remaining root canal filling and post space preparation against coronal leakage of Enterococcus faecalis. Forty-one roots of maxillary incisors were biomechanically prepared, maintaining standardized canal diameter at the middle and coronal thirds. The roots were autoclaved and all subsequent steps were undertaken in a laminar flow chamber. The canals of 33 roots were obturated with $\mathrm{AH}$ Plus sealer and gutta-percha. The root canal fillings were reduced to 3 predetermined lengths $(\mathrm{n}=11)$ : $\mathrm{G} 1=6 \mathrm{~mm}, \mathrm{G} 2=4 \mathrm{~mm}$ and $\mathrm{G} 3=2 \mathrm{~mm}$. The remaining roots served as positive and negative controls. Bacterial leakage test apparatuses were fabricated with the roots attached to Eppendorf tubes keeping $2 \mathrm{~mm}$ of apex submerged in BHI in glass flasks. The specimens received an $E$. faecalis inoculum of $1 \times 107 \mathrm{cfu} / \mathrm{mL}$ every 3 days and were observed for bacterial leakage daily during 60 days. Data were submitted to ANOVA, Tukey's test and Fisher's test. At 60 days, G1 $(6 \mathrm{~mm})$ and G2 $(4 \mathrm{~mm})$ presented statistically similar results $(\mathrm{p}>0.05)(54.4 \%$ of specimens with bacterial leakage) and both groups differed significantly $(\mathrm{p}<0.01)$ from $\mathrm{G} 3(2 \mathrm{~mm})$, which presented $100 \%$ of specimens with E. faecalis leakage. It may be concluded that the shortest endodontic obturation remnant leaked considerably more than the other lengths, although none of the tested conditions avoids coronal leakage of E. faecalis.
\end{abstract}

Keywords: Bacterial infiltration, E. faecalis, root canal treatment.

\section{INTRODUCTION}

The advent of prefabricated intraradicular posts and adhesive materials allied to the trend of preservation of sound dental structure increased the restorative options and allowed better utilization of the tooth remnant. Teeth with extensive coronal destruction may be rehabilitated in a single appointment by the placement of an intraradicular post and core immediately after completion of root canal obturation, thus minimizing the risk of salivary and bacterial contamination of the remaining root canal filling (10).

The use of newer adhesive systems and prefabricated intraradicular posts has provided an adequate retention with cementation of smaller posts, thus maintaining a larger portion of obturating material to seal the middle and apical root thirds
(5). Nevertheless, in teeth with short or curved roots, the length of the intraradicular post will be reduced, which may compromise its retention. In these cases, only few millimeters of root filling material will be left in the canal and will be responsible to maintain the health of the periradicular tissues.

Several studies have considered coronal leakage as an important cause of endodontic treatment failure. It has been demonstrated that root fillings exposed to the oral cavity are invariably contaminated by fluids, bacteria and their byproducts. Long-term contamination may lead to failure of endodontics and compromise the restorative/prosthetic treatment as a whole $(1,8,21,22,25)$.

The maintenance of aseptic conditions during root canal therapy avoids microbial and fluid infiltration. However, the sequence of post space preparation procedures in endodontically

*Corresponding Author. Mailing address: Rua Célia de Oliveira Meirelles 350, 14024-070 Ribeirão Preto, SP, Brasil. Phone/Fax: +55 $163603-6783$. E-mail: sousanet@forp.usp.br 
treated teeth, which includes impression, fitting of the intraradicular post to the prosthetic space and post cementation, may allow inadvertent contact of the remaining root canal filling with saliva and bacteria $(10,12,14)$.

The length of the intraradicular post and the residual filling material are also very important. The intracanal retainer should have $2 / 3$ of the bone-supported root length. When this length is not clinically feasible, the post should be at least as long as the clinical tooth crown (18). Some authors have advocated that a minimum of $4 \mathrm{~mm}$ of filling material should remain in the root canal to prevent bacterial leakage $(15,24)$.

The purpose of this study was to evaluate in vitro the sealing ability of different lengths of remaining root canal filling $(6 \mathrm{~mm}$, $4 \mathrm{~mm}$ and $2 \mathrm{~mm}$ ) after obturation and immediate post space preparation against coronal leakage of Enterococcus faecalis during a 60-day experimental period.

\section{MATERIALAND METHODS}

This research was approved by the Ethical Committee in Research of University of Ribeirão Preto, São Paulo, Brazil.

\section{Selection and Preparation of Teeth}

Extracted human maxillary central incisors were selected from a random collection and were checked for absence of root caries, cracks and structural defects. Soft debris were removed with hand curettes. Crowns were removed at the cementoenamel junction with a water spray-cooled carborundum disc, and the roots were trimmed coronally to a uniform length of $14 \mathrm{~mm}$ and stored in saline at $9^{\circ} \mathrm{C}$ until use to prevent dehydration.

\section{Endodontic Procedure}

The working length (WL) was established $1 \mathrm{~mm}$ short of the anatomical apex. A size 40 K-file (Dentsply/Maillefer, Ballaigues, Switzerland) was selected as a master apical file (MAF) and 41 specimens whose canal diameter at WL coincided with the size of the MAF were included in the study. The apical plateau was prepared with the subsequent three file sizes larger than the MAF at the WL. The root canals were instrumented according to the step back technique and were irrigated with $2 \mathrm{~mL}$ of $1 \%$ sodium hypochlorite (Merck, Darmstadt, Germany) at every change of file. Biomechanical preparation was completed with enlargement of the coronal root third with \#6 Largo burs (Dentsply/Maillefer, Ballaigues, Switzerland) to standardize the root portion that should further receive the bacterial inoculum. Final flushing was done with $5 \mathrm{ml}$ of 17\% EDTA (Merck, Darmstadt, Germany), which remained in root canals for 3 minutes, followed by irrigation with $10 \mathrm{~mL}$ of distilled water, aspiration and drying of the root canals with sterile absorbent paper points (Dentsply/Herpo, Petrópolis, RJ, Brazil).

The instrumented roots were autoclaved at $120^{\circ} \mathrm{C}$ during 20 minutes (Autoclave model 103; Fabbe Primar, São Paulo, SP,
Brazil) and, thereafter, all procedures were performed in a laminar flow chamber (Veco, Campinas, SP, Brazil) for maintenance of the aseptic chain. All instruments and materials were sterilized before use.

The root canals were obturated with AH Plus sealer (Dentsply De Trey, GmbH, Konstanz, Germany) and lateral condensation of gutta-percha cones (Dentsply/Herpo, Petrópolis, RJ, Brazil), which were disinfected by immersion in $2.5 \%$ sodium hypochlorite for 3 minutes prior to use. After obturation, radiographs of all specimens were taken to evaluate the quality of the root canal filling. Specimens used this experiment had radiographically well-compacted fillings that extended to $1 \mathrm{~mm}$ short of the apical foramen.

Thirty-three roots were randomly assigned to three groups $(\mathrm{n}=11)$, according to the length of the remaining root canal filling: $\mathrm{G} 1-6 \mathrm{~mm}, \mathrm{G} 2-4 \mathrm{~mm}$ and $\mathrm{G} 3-2 \mathrm{~mm}$. The other 8 roots served as positive $(n=4)$ and negative $(n=4)$ controls. The teeth used as positive controls were instrumented but not obturated to demonstrate the maximum bacterial leakage through the root canal system. The negative control teeth were instrumented, not obturated and thorough sealed externally with nail polish in order to check the method (confirm that the impermeabilization was able to avoid bacterial infiltration). Immediately after obturation, the root canal fillings were reduced to the predetermined lengths $(2,4$ and $6 \mathrm{~mm})$ using a heated plugger. Vertical force was applied with a cold instrument to compact the remaining mass. The obturated teeth were radiographed to check the homogeneity of the remaining filling material. A Hedstrom file (Dentsply/Maillefer, Ballaigues, Switzerland) with a rubber stopper was inserted into the canals to confirm the length of root filling remnants. The specimens were stored at $37^{\circ} \mathrm{C}$ for 24 hours, which corresponds to 3 times the time required for complete set of the endodontic sealer, according to the manufacturer's instructions.

The roots in the experimental groups and positive control group were coated with two layers of cosmetic nail polish (Colorama, Maybelline, NY, USA), except for the apical $1 \mathrm{~mm}$. The roots used as negative controls had the entire root surface sealed.

\section{Leakage Apparatus Preparation}

For the bacterial leakage test, one test apparatus was fabricated for each specimen. Briefly, the tapered end of sterile 1.5-mL-Eppendorf plastic tubes (Eppendorf-Elkay, Shrewsbury, MA, USA) was perforated with a scalpel blade (Med. S. N., Shanghai, China) and the obturated roots were individually inserted until their apical $2 \mathrm{~mm}$ protruded through the tube end. The junction between each tube and root was sealed with epoxy resin (Araldite, Brascola Ltda, São Paulo, SP, Brazil) to prevent leakage of the connection.

The Eppendorf tube/root assemblies were placed in sterile 13-mL glass flasks containing $9 \mathrm{~mL}$ of brain heart infusion (BHI) 
broth (Oxoid Ltda, Basingstoke, Hampshire, England), in which the root apexes remained completely submerged. To avoid external contamination, the interface between the Eppendorf tubes and the glass flasks was sealed tightly with epoxy resin. The test assemblies were then incubated at $37^{\circ} \mathrm{C}$ for 24 hours to confirm sterility. Fig. 1 presents a schematic illustration of the apparatus used for microbial infiltration.

\section{Culture and Preparation of the Enterococcus faecalis suspension}

Enterococcus faecalis ATCC 29212 was used for the leakage test. A total of $200 \mu \mathrm{L}$ of the microbial strain were cultured overnight in $2 \mathrm{~mL}$ of BHI broth at $37^{\circ} \mathrm{C}$. The bacterial suspension was added to $2 \mathrm{~mL}$ of saline and adjusted to achieve a turbidity equivalent to $0.5 \mathrm{McF}$ arland standard in order to ensure a bacterial concentration of approximately $1.5 \times 10^{8}$ colony forming units $(\mathrm{cfu}) / \mathrm{mL}$. For preparation of the inoculum, the culture was diluted by transferring $200 \mu \mathrm{L}$ of the $E$. faecalis suspension to a hemolysis tube containing $1.8 \mathrm{~mL}$ of $\mathrm{BHI}$, thus providing a concentration of $1 \times 10^{7} \mathrm{cfu} / \mathrm{mL}$.

\section{Bacterial Leakage Test}

An inoculum of $E$. faecalis $(10 \mu \mathrm{L})$ was injected into the post/canal space of the test specimens and positive controls using a micropipette (Finnpipette, Labsystems, Helsinki, Finland). The inoculum was changed with fresh inoculum every 3 days during a 60-day experimental period or up to the occurrence of bacterial growth. The negative controls did not receive bacterial inoculum. The test apparatuses were placed in plastic receptacles and incubated in a microbiological stove at $37^{\circ} \mathrm{C}$ during the course of the experiment. Bacterial growth was checked every 24 hours.

Turbidity of the BHI broth in which the roots inoculated with $E$. faecalis were submerged was indicative of bacterial growth due to leakage of the test strain. The day of occurrence

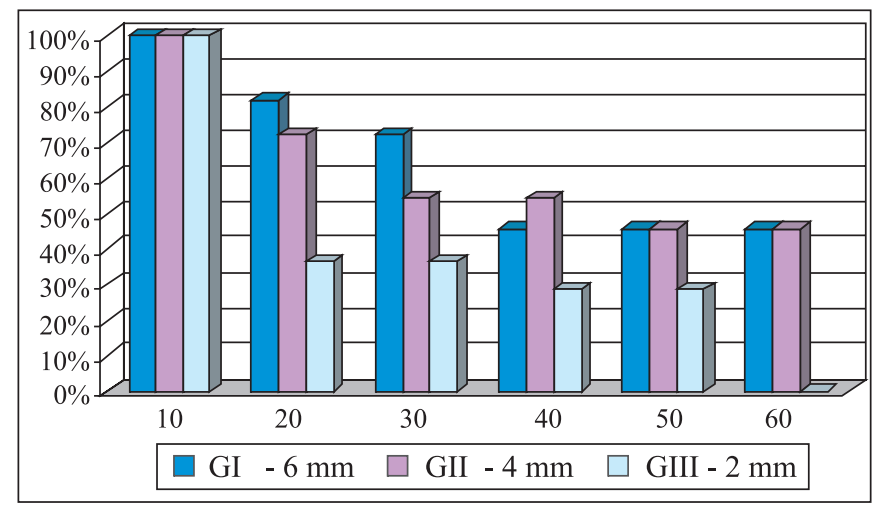

Figure 1. Schematic illustration of the apparatus used for microbial infiltration. and code number of the specimen were recorded and the content was collected and submitted to microbiological assays. The specimens with bacterial leakage were removed from the test apparatuses and the root canals were dried with sterile absorbent paper points and a new inoculum was injected into the post/ canal space. The soaked paper points were incubated overnight in $\mathrm{BHI}$ broth at $37^{\circ} \mathrm{C}$ for analysis of the material collected from the root canals.

Bacterial growth was identified as E. faecalis by means of a series of microbiological tests, namely, colonial morphology, cell morphology, positive bile-esculin test and growth in $6.5 \%$ $\mathrm{NaCl} \mathrm{BHI} \mathrm{broth.} \mathrm{Samples} \mathrm{were} \mathrm{excluded} \mathrm{if} \mathrm{there} \mathrm{were} \mathrm{signs} \mathrm{of}$ contamination with other bacteria.

Analysis of colonial morphology in Müeller Hinton agar plates. Samples of BHI broth retrieved from the test apparatuses, cultured paper points and bacterial inoculum were collected, seeded onto agar Müeller Hinton plates (Merck, Darmstadt, Germany) and incubated at $37^{\circ} \mathrm{C}$ for 24 hours to verify the occurrence of E. faecalis growth by analysis of colonial morphology.

Cell Morphology. After agar plate culture, smears were prepared on glass slides and stained with Gram's Method to identify microbial morphology.

Bile-esculin agar test. Samples of colonial growth on agar plates were collected, seeded on bile-esculin agar (Merck, Darmstadt, Germany) and incubated at $37^{\circ} \mathrm{C}$ for 24 hours to verify the presence of Streptococcus sp. The bile-esculin agar test is based on the capacity of some bacteria to hydrolyze esculin in the presence of bile. Bacterial growth on this medium forms a black complex because the esculin reacts with ferric ions. A positive result is indicative of the presence of Streptococcus sp., among which there may be samples of E. faecalis.

$6.5 \% \mathrm{NaCl}$ tolerance test. This test is used to check microbial capacity to grow on the presence of $6.5 \% \mathrm{NaCl}$, distinguishing Enterococcus spp. (which grow on the presence $\mathrm{NaCl}$ ) from Streptococcus spp. Samples of colonial growth on agar plates were collected, seeded on $6.5 \% \mathrm{NaCl} \mathrm{BHI}$ broth (Merck, Darmstadt, Germany) and incubated overnight at $37^{\circ} \mathrm{C}$. Turbidity of BHI broth within 24 hours indicated the presence of $E$. faecalis.

Data were submitted to ANOVA and Tukey's at 1\% significance level to verify the differences among the groups and to determine which groups differed significantly to the others. Fisher's exact test was performed to identify the intergroup differences at the evaluated time points, with a value of $\mathrm{p}<0.05$ being considered statistically significant.

\section{RESULTS}

Mean values and standard deviations of specimens without bacterial leakage in the three experimental groups are given on Table 1. 
There was statistically significant difference $(\mathrm{p}<0.01)$ among the lengths of remaining root canal filling. Group $1(6 \mathrm{~mm})$ and Group $2(4 \mathrm{~mm})$ did not differ significantly to each other $(\mathrm{p}>0.01)$ and presented a larger number of specimens without $E$. faecalis leakage during the course of the experiment. On the other hand, Group $3(2 \mathrm{~mm})$ presented a smaller number of specimens without bacterial leakage and was statistically significant different from the other groups $(\mathrm{p}<0.01)$.

Fisher's exact test was applied to the data obtained at 10day intervals from the 20th to the 60th day because no turbidity of the medium (bacterial leakage) was observed up to the 10th day in either of the groups. Fig. 2 depicts graphically the number of specimens without $E$. faecalis leakage in the three groups at 10-day intervals. At 20 days, there was statistically significant difference $(\mathrm{p}<0.05)$ only between Group $1(6 \mathrm{~mm})$ and Group $3(2 \mathrm{~mm})$, the group with longer remaining root canal filling presenting a larger number of specimens without bacterial

Table 1. Means of the number of specimens without bacterial leakage in the three groups.

\begin{tabular}{cc}
\hline $\begin{array}{c}\text { Lengths of remaining } \\
\text { filling material }\end{array}$ & Means $( \pm$ SD $)$ \\
\hline G1 $-6 \mathrm{~mm}$ & $7.90( \pm 2.46) \mathrm{a}$ \\
$\mathrm{G} 2-4 \mathrm{~mm}$ & $7.18( \pm 1.99) \mathrm{a}$ \\
$\mathrm{G} 3-2 \mathrm{~mm}$ & $5.17( \pm 3.78) \mathrm{b}$ \\
\hline
\end{tabular}

Different letters indicate statistically significant difference at $1 \%$; Tukey critical value $=1.46$.

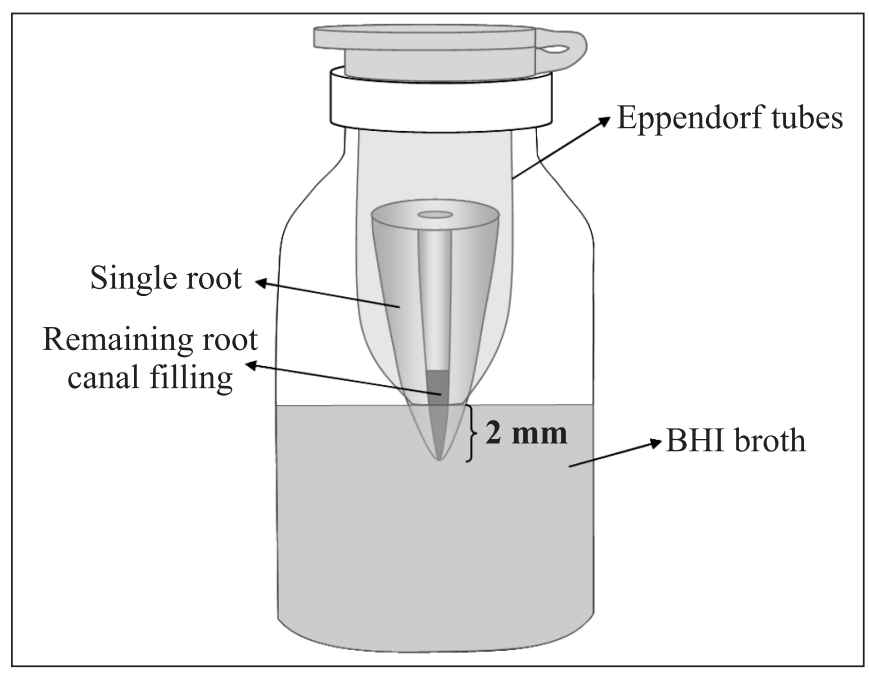

Figure 2. Graphic presentation of the number of specimens without $E$. faecalis leakage in the three groups at 10-day intervals. infiltration. Nevertheless, at 30, 40 and 50 days, no statistically significant difference was observed among the groups $(p>0.05)$. At 60 days, Group $1(6 \mathrm{~mm})$ was statistically similar to Group 2 $(4 \mathrm{~mm})(\mathrm{p}>0.05)$ and both differed significantly from Group 3 (2 $\mathrm{mm})(\mathrm{p}<0.05)$, in which $100 \%$ of specimens presented $E$. faecalis leakage.

The positive controls demonstrated bacterial leakage after 1 day, whereas the negative controls did not show leakage for the entire observation period.

Samples of the broth retrieved from the test apparatuses, cultured paper points and bacterial inoculum were positive for E. faecalis as for counterproof, colonial morphology, $6.5 \% \mathrm{NaCl}$ tolerance test, bile-esculin test and cell morphology.

\section{DISCUSSION}

Coronal leakage has been pointed out as one of the most important and challenging causes of endodontic failure because it compromises sealing of the root canal system $(3,7,12,21,22)$.

It has been demonstrated that oral fluids, bacteria and their byproducts may infiltrate through the marginal gaps of defective restorations and penetrate the interface between the root filling material and the root canal walls, reaching the periapical region within a relatively short time $(3,4,7,8,21,22)$. This scenario is worsened in case of teeth with extensive coronal tooth loss that implicates in the placement of intraradicular posts because of following factors associated with post space preparation and post cementation: break of the aseptic chain during procedures undertaken without rubber dam isolation, possibility of dislodging the obturation during removal of the coronal portion of the filling material, placement of temporary restorations between the prosthetic working sessions and length of the remaining root canal filling.

Among the currently available methods to evaluate the quality of root filling seal, dye marginal leakage is the most frequently used model. However, this methodology is not the most effective and has some limitations, as the size of dye molecules may overestimate the infiltration or the interaction between dye and sealer may lead to false results (23).

It has been demonstrated that tests using bacteria as tracer agents of leakage may simulate in a more reliable manner what actually occurs under clinical conditions, as they allow a dynamic interaction between the tested bacterial strain and the root canal sealer $(11,14,20,21,24,25)$. E. faecalis is the most often retrieved pathogen in asymptomatic endodontic infections because of its capacity to invade dentinal tubules, compete with other microorganisms and resist nutritional privation. It is a facultative anaerobic Gram-positive coccus that may present either isolated, in pairs or in chains $(4,16,17,20)$.

Regarding the methodology used in the present study (coronal leakage of E. faecalis), root length, MAF and diameter of the coronal root third were standardized to allow that the 
same amount of bacterial inoculum was placed in contact with the root filling material within the post space. The roots were autoclaved after instrumentation and thereafter all procedures were performed in a laminar flow chamber. Sterility of the test assemblies was confirmed by absence of turbidity of the medium. Purity of the bacterial inoculum used for contamination of the specimens and purity of the material retrieved from the specimens at each renewing of the inoculum were confirmed by a set of microbiological assays including colonial morphology in agar Müeller Hinton plates, cell morphology, bile-esculin test and $6.5 \% \mathrm{NaCl}$ tolerance test. The results of all tests were positive to the presence of E. faecalis as the sole microbial strain.

Two aspects should be discussed in the light of the results of the present study: bacterial leakage through the residual root canal obturation and the time elapsed until its occurrence. E. faecalis penetration through the obturating material was observed in all experimental groups. Bacterial leakage was statistically similar in the groups with 6 and $4 \mathrm{~mm}$ of remaining filling material and, comparatively, significantly smaller in the group with $2 \mathrm{~mm}$ of root filling remnant. At the end of an experimental period of 60 days, Group 3 (2 mm of remaining filling material) exhibited $100 \%$ of specimens with $E$. faecalis leakage. The greatest coronal bacterial leakage observed in Group 3 may be explained by the high incidence of lateral and accessory canals in the apical region (6). It is likely that the specimens in which the length of the root filling remnant was 6 or $4 \mathrm{~mm}$ (Groups 1 and 3) had better apical sealing. However, even in these groups the residual obturation was not capable of preventing bacterial leakage, probably due to the presence of gaps at the interface between the filling material and the root canal walls. These interfacial defects may be attributed to variables such as internal anatomy of the root canal system, biomechanical preparation, proprieties of endodontic irrigants, physicochemical proprieties of endodontic materials and root filling techniques (16).

The findings of the present study, in which bacterial leakage occurred regardless of the length of the remaining root canal filling, are consistent with those of previous investigations $(1,3,7,8,10,21,22,25)$. Regarding the time elapsed until the occurrence of $E$. faecalis leakage, broth turbidity was not observed in any of the groups up to the 10th day of the experiment. According to Pizzo et al., (13), AH Plus sealer, used in this study, presents bacterial inhibition within the first 24 hours, which may have delayed bacterial penetration but was not able to completely prevent coronal leakage of E. faecalis. Therefore, an important role of the endodontic obturation is the formation of a physical barrier to prevent bacteria from reaching the apical region and periapical tissues (16). In Group 1 (root filling remnant of $6 \mathrm{~mm}$ ), this physical barrier was 3 times larger than that in Group 3 (root filling remnant of $2 \mathrm{~mm}$ ), which may possibility explain the difference observed between these groups at 20 days concerning the number of specimens with bacterial leakage.

It is worthy mentioning that, owing to its high flow capacity and long setting time, AH Plus epoxy resin-based sealer is able to penetrate deeply into micro-gaps and micro-defects. These properties have been claimed to enhance the dentin/sealer interweaving (19), increase the resistance to removal and/or dislodgment from dentin surface and reduce marginal infiltration $(9,16,21)$. Some factors that may contribute to attainment of different results with respect to bacterial leakage time include study protocol, type of microorganism and its concentration, dental anatomy, amount of remaining tooth structure and sample size (3). Therefore, comparison of the findings of the present study to those published elsewhere should be done with care because of methodological differences.

Torabinejad et al. (22) have demonstrated that $P$. vulgaris was able to penetrate through obturated root canals in a mean time of 49 days and that $S$. epidermidis reached the root apex within 24 days. Gish et al. (7) reported that penetration of $S$. anginosus occurred within 71 days, while Khayat et al. (8) observed bacterial leakage between 4 and 48 days. Barrieshi et al. (3) assessed bacterial leakage of a mixed anaerobic community of organisms in obturated canals after post space preparation and observed that the time of bacterial penetration ranged from 48 to 84 days.

E. faecalis may remain viable in the root canals for up to 13 months, being the main microorganism involved in the onset of secondary endodontic infections $(17,20)$. Histological analysis using H.E. and Brown \& Brenn staining techniques reveals the presence of bacteria in the root canal lumen and lodged into the dentinal tubules, which confirms the capacity of penetration of this microorganism.

Despite the currently available wide array of root canal filling materials and techniques, the findings of different studies $(12,14,25)$ have systematically demonstrated that, to date, none of them is able to completely prevent the occurrence of coronal or apical leakage, which makes the concept of a hermetic sealing hardly achievable in Endodontics.

The findings of the present study and the research-based evidences discussed herein emphasize the need to establish treatment protocols for endodontically treated teeth that require the placement of intraradicular posts in order to prevent bacterial invasion and failure of the obturation. Recommendable measures include the fabrication of plugs to protect the remaining filling material (2) and use of prefabricated posts and adhesive systems to reduce the number of clinical sessions and avoid exposure of the root filling to the oral cavity.

Within the limitations of an in vitro study, it may be concluded that, it may be concluded that the shortest endodontic obturation remnant leaked considerably more than the other lengths, although none of the tested conditions avoid coronal leakage of E. faecalis. 


\section{RESUMO}

\section{Influência do comprimento do material obturador remanescente no canal radicular e preparo do espaço protético na infiltração coronária do Enterococcus Faecalis}

Este estudo avaliou a capacidade de diferentes de remanescentes de material obturador do canal radicular e preparo do espaço protético na infiltração do Enterococcus faecalis. Quarenta e uma raízes de incisivos superiores foram preparadas biomecanicamente, mantendo-se diâmetro padronizado nos terços médio e cervical. As raízes foram autoclavadas e todos os passos subseqüentes foram realizados em capela de fluxo laminar. Os canais de 33 raízes foram obturadors com AH Plus e guta-percha. As obturações foram reduzidas a 3 comprimentos $(\mathrm{n}=11): \mathrm{G} 1=6 \mathrm{~mm}, \mathrm{G} 2=4 \mathrm{~mm}$ e G3=2 $\mathrm{mm}$. As raízes remanescentes serviram de controles positivo e negativo. $\mathrm{O}$ dispositivo para testar a microinfiltração bacteriana foi confeccionado com as raízes fixas a Eppendorfs, mantendo-se $2 \mathrm{~mm}$ do ápice submergido em vidro contendo BHI. Os dentes receberam o inóculo de $1 \times 10^{7} \mathrm{UFC} / \mathrm{ml}$ de E. faecalis a cada 3 dias, com observação diária por 60 dias. Os dados obtidos foram submetidos à análise de variância, teste de Tukey e Fisher. Foi possível observar que aos 60 dias, o G1 (6 mm) e G2 (4 mm) apresentou resultados estatisticamente semelhantes $(p>0,05)$ ( $54 \%$ dos espécimes com infiltração bacteriana) e ambos os grupos foram diferentes estatisticamente $(\mathrm{p}<0,01)$ do $\mathrm{G} 3(2 \mathrm{~mm})$, o qual apresentou $100 \%$ de espécimes com microinfiltração. Concluiu-se que apesar da infiltração do E. faecalis ter ocorrido em todas as condições testadas, aparentemente houve uma correlação positiva entre o comprimento do remanescente radicular e a eficácia do selamento, uma vez que, a menor a obturação remanescente infiltrou consideravelmente mais que os outros comprimentos.

Palavras-chave: Infiltração bacteriana, E. faecalis, tratamento dos canais radiculares

\section{REFERENCES}

1. Alves, J.; Walton, R.; Drake, D. (1998). Coronal leakage: Endotoxin penetration from mixed bacterial communities trough obturated post prepared root canals. J. Endod. 24 (9), 587-591.

2. Barbosa, H.G.; Holland, R.; Sousa, V.; Dezan Junior, E.; Bernabé, PFE.; Otoboni-Filho, J.A.; Nery, M.J. (2003). Healing process of dog teeth after post space preparation and exposition of the filling material to the oral environment. Braz. Den.t J. 14 (2), 103-108.

3. Barrieshi, K.M.; Walton, R.E.; Johnson, W.T.; Drake, R. (1997). Coronal leakage of mixed anaerobic bacteria after obturation and post space preparation. Oral Surg. Oral Med. Oral Pathol. Oral Radiol. Endod. 84 (3), 310-4.

4. Baumgartner, G.; Zehnder, M.; Paqué, F. (2007). Enterococcus faecalis type strain leakage through root canals filled with GuttaPercha/AH plus or Resilon/Epiphany. J. Endod. 33 (1), 45-47.
5. Braga, N.M.A.; Paulino, S.M.; Alfredo, E.; Sousa-Neto, M.D.; Vansan, L.P. (2006). Removal resistance of glass-fiber and metallic cast posts with different lengths. J. Oral Sci. 48 (1), 15-20.

6. De Deus, Q.D. (1975). Frequency, location, and direction of the lateral, secondary and accessory canals. J. Endod. 1, 361-6.

7. Gish, S.P.; Drake, D.R.; Walton, R.E.; Wilcox, L. (1994). Coronal leakage: bacterial penetration through obturated canals following post preparation. J. Am. Dent. Assoc. 125 (10), 1369-1372.

8. Khayat, A.; Lee, S.J. (1993). Torabinejad M. Human saliva penetration of coronally unsealed obturated root canals. J. Endod. 19 (9), 458-60.

9. Kopper, P.M.; Figueiredo, J.A.; Della Bona, A.; Vanni, J.R.; Bier, C.A.; Bopp, S. (2003). Comparative in vivo analysis of the sealing ability of three endodontic sealers in post-prepared root canals. Int. Endod. J. 36 (12), 857-863.

10. Metzger, Z.; Abramovitz, R.; Abramovitz, I.; Tagger; M. (2000). Correlation between remaining length of root canal filling after immediate post space preparation and coronal leakage. J. Endod. 26 (12), 724-727.

11. Monticelli, F.; Sadek, F.T.; Schuster, G.S.; Volkmann, K.R.; Looney, S.W.; Ferrari, M.; Toledano, M.; Pashley, D.H.; Tay, F.R. (2007). Efficacy of two contemporary single-cone filling techniques in preventing bacterial leakage. J. Endod. 33 (3), 310-313.

12. Pappen, A.F.; Bravo, M.; Gonzalez-Lopes, S.; Gonzales-Rodriques, M.P. (2005). An in vitro study of coronal leakage after intraradicular preparation of cast-dowel space. J. Prosthet. Dent. 94 (3), 214-218.

13. Pizzo, G.; Giammanco, G.M.; Cumbo, E.; Nicolosi, G.; Gallina, G. (2006). In vitro antibacterial activity of endodontic sealers. J. Dent 34 (1), 35-40.

14. Prado, C.J.; Estrela, C.; Panzeri, H.; Biffi, J.C.G. (2006). Permeability of remaining endodontic obturation after post preparation. Gen. Dent. 54 (1), 41-43.

15. Raiden, G.C.; Gendelman, H. (1994). Effect of dowel space preparation on the apical seal of root canal fillings. Endod. Dent. Traumatol. 10 (3), 109-112.

16. Saleh, I.M.; Ruyter, I.E.; Haapasalo, M.; Orstavik, D. (2004). Survival of Enterococcus faecalis in infected dentinal tubules after root canal filling with different root canal sealers in vitro. Int. Endod. J. 37 (3), 193-198.

17. Sedgley, C.; Buch, G.; Appelbe, O. (2005). Prevalence of Enterococcus faecalis at multiple oral sites in endodontic patients using culture and PCR. J. Endod. 32 (2), 104-109.

18. Shillingburg Jr, H.T.; Fiser, D.W.; Dewhirst, R.B. (1970). Restoration of endodontically treated posterior teeth. J. Prosthet. Dent. 24 (5), 401-409.

19. Sousa-Neto, M.D.; Marchesan, M.A.; Pecora, J.D.; Junior, A.B.; Silva-Sousa, Y.T.; Saquy, P.C. (2002). Effect of Er:YAG on adhesion of root canal sealers. J. Endod. 28 (3), 185-187.

20. Stuart, C.H.; Schwartz, S.A.; Beesom, T.J.; Owatz, C.B. (2006). Enterococcus faecalis: Its role in root canal treatment failure and current concepts in retreatment. J. Endod. 32 (2), 93-98.

21. Timpawat, S.; Amornchat, C.; Trisuwan, W. (2001). Bacterial coronal leakage after obturation with three root canal sealers. J. Endod. 27(1), 36-39

22. Torabinejad, M.; Ung, B.; Kettering, J.D. (1990). In vitro bacterial penetration of coronally unsealed endodontically treated teeth. $J$. Endod. 16 (12), 566-569.

23. Wu, M.K.; Degee, A.J.; Wesselink, P.R.; Moorer, W.R. (1993). Fluid transport and bacterial penetration along root canal. Int. Endod. J. 26 (4), 203-208.

24. Wu, M.K.; Pehlivan, Y.; Kontakiotis, E.G.; Wesselink, P.R. (1998). Microleakage along apical root fillings and cemented posts. $J$. Prosthet. Dent. 79 (3), 264-269.

25. Yucel, A.C.; Guler, E.; Guler, A.U.; Ertas, E. (2006). Bacterial penetration after obturation with four different root canal sealers. $J$. Endod. 32 (9), 890-893. 